\title{
UNCONSCIONABLE CONTRACTS UNDER THE UNIFORM COMMERCIAL CODE
}

\section{INTRODUCTION}

One of the most controversial and least understood sections of the Uniform Commercial Code is section 2-302, dealing with unconscionable contracts or clauses. The section provides:

(1) If the court as a matter of law finds the contract or any clause of the contract to have been unconscionable at the time it was made the court may refuse to enforce the contract, or it may enforce the remainder of the contract without the unconscionable clause, or it may so limit the application of any unconscionable clause as to avoid any unconscionable result.

(2) When it is claimed or appears to the court that the contract or any clause thereof may be unconscionable the parties shall be afforded a reasonable opportunity to present evidence as to its commercial setting, purpose and effect to aid the court in making the determination. ${ }^{1}$

This section has been characterized as embodying a new social concept which will enable the courts to invalidate or remake many contracts on the basis of a vague discretionary standard. Such criticism betrays fears of "wildcat law-suits by over-optimistic counsel," of strike suits that will be settled for nuisance value, of holdup defenses that will force settlement, and, most significantly, of a disruptive effect on business affairs, which rely heavily upon the stability of contractual arrangements. ${ }^{2}$

The anxiety concerning this admittedly novel ${ }^{3}$ development in our sales law demands a determination of the reach of the section as applied to

1 UNIForm Commercial Code $\$ 2-302$. Six states have enacted the Code. Conn. Acts 1959, Pub. Act No. 133 (effective Oct. 1, 1961); Ky. Acts 1958, ch. 77; Mass. Ann. Laws ch. 106 (1958); PA. Stat. AnN. tit. 12A (1954), as amended, Pa. Stat. ANN. tit. 12A (Supp. 1959) ; R.I. Laws 1960, tit. 6A (effective Jan. 2, 1962); see N.H. Laws 1959, ch. 247, \$1 (effective July 1, 1961). Preparation is being made for the presentation of the Code to the 1961 legislatures of thirteen states: Arkansas, California, Illinois, Maine, Montana, New Jersey, New Mexico, Ohio, Oklahoma, Oregon, Washington, Wisconsin, and Wyoming. See 28 U.S.L. WEEK 2584 (May 24, 1960).

21 N.Y. Law Revision Commission, Study of the Uniform Commercial Code 63-64 (1955) ; N.Y. LAW ReVISION CoMmissIoN, REPORT RELATING to THE UNIFORM COMMERCIAL CODE 37 (1956); Note, Definition and Interpretation of Unconscionable Contracts, 58 Dick. L. REv. 161 (1954); Note, Policing Contracts Under the Proposed Commercial Code, 18 U. CHI. L. Rev. 146 (1950). But see Latty, Sales and Title and the Proposed Code, 16 LAW \& Contemp. ProB. 3, 19 \& n.78 (1951); Note, 45 VA. L. Rev. 583, 591 (1959); Note, 63 Yale L.J. 560 (1954).

3 The comment to $\$ 2-302$ states that there is no prior uniform statutory provision on which the section is based. See Pennsylvania Annotatrons to the 
current sales practice. Although the term "unconscionability" 4 has seldom been explicitly judicially construed, ${ }^{5}$ the courts by various semicovert devices ${ }^{6}$ have provided a body of law from which a doctrine of unconscionability can be drawn. From the underlying rationale of these cases certain common factors can be isolated which will serve as guidelines for predicting the future application of section 2-302. These factors indicate that the provision empowers the courts to do directly what they have long been doing indirectly.7 To supplement this investigation, a comparative analysis of the similarly oriented civil-law doctrines of gute Sitten in Germany ${ }^{8}$ and ordre public in France ${ }^{9}$ offers an opportunity to evaluate the concept of unconscionability in a setting where it is explicitly invoked. This Note will seek to demonstrate that the Uniform Commercial Code provision introduces into the law of sales a much needed principle that will lend order to existing inconsistency without impinging upon the doctrine of "freedom of contract."

\section{Legislative History}

A study of the history of section 2-302 gives only a general indication of its intended operation. Perhaps the most revealing feature of this development is the tendency of the draftsmen to broaden the section's applicability. When first proposed in 1944 as section 23 of the Uniform Revised Sales Act, the operation of the unconscionability principle was

Proposed Uniform Commercial Code 8, 18 (1952); Cosway, Sales-A Comparison of the Law in Washington and the Uniform Commercial Code, 35 WASH. L. REv. 412, 426 (1960); A Symposinm of the Proposed Uniform Commercial Code-Sales, 17 Albany L. Rev. 11, 22-23 (1953).

4 Although no cases can be found which have stricken a contract or clause under $\S 2-302$, Henningsen v. Bloomfield Motors, Inc., 32 N.J. 358, 161 A.2d 69 (1960), which arose in a state which has not yet adopted the Code, cited it by way of analogy. Id. at 404,161 A.2d at 95 . (Although the report reads $\$ 202$, the context makes it obvious that $\$ 2-302$ was intended.). The approach of the court in Henningsen would seem apposite for a court applying $\$ 2-302$ in light of the factors considered by the court in voiding the disclaimer.

5 One of the few cases where it was expressly considered is Hume v. United States, 132 U.S. 406 (1889), which adopted the definition found in Earl of Chesterfield v. Janssen, 2 Ves. Sen. 125, 155, 28 Eng. Rep. 82, 100 (1750): an unconscionable bargain is one "such as no man in his senses and not under delusion would make on the one hand, and as no honest and fair man would accept on the other ...." Other attempts by the courts to state a definition are similarly vague. See Frankilin Fire Ins. Co. v. Noll, 115 Ind. App. 289, 294, 58 N.E.2d 947, 949 (1945); Stiefler v. McCullough, 97 Ind. App. 123, 130, 174 N.E. 823, 826 (1931) (alternative holding).

6 See Llewellyn, What Price Contract?-An Essay in Perspective, 40 YALE L.J. 704, 733-36 (1931); Note, Contract Clanses in Fine Print, 63 Harv. L. Rev. 494 (1950) ; Note, Grower-Canner Agreements: An Abuse of Mass Standardized Contracts, 58 YALE L.J. 1161 (1949); Note, Warranties of Kind and Quality Under the Uniform Revised Sales Act, 57 YaLE L.J. 1389, 1401-04 (1948); Llewellyn, Book Review, 52 Harv. L. REv. 700 (1939).

7 Hawkland, Sales and Bulk Sales Under the. Uniform Commerctal Code 22-24 (1958); Pennsylvania Annotations to the Proposed Uniform Commercial CODE 18 (1952).

8 See notes 86-89, 95-102 infra and accompanying text.

9 See notes 90-94 infra and accompanying text. 
limited to form contract clauses; $; 0$ their widespread use by industry underlay the decision that reform of the law dealing with such contracts was most urgent. This purpose was still foremost in the proponents' minds when the first tentative draft of the Uniform Commercial Code was issued in 1949.11 At this time another equally common situation was also noted: that in which a party has knowingly acquiesced in a one-sided and oppressive bargain. ${ }^{12}$ To both circumstances-the unbargained agreement to a form contract and the assent to an oppressive bargain-the section was "intended to apply ... the equity courts' ancient policy of policing contracts for unconscionability or unreasonableness." 13

When the time came to submit a final draft for state legislative approval, however, reference to the equity doctrine was deleted in favor of the more general "basic test" found in the current comment to the section.14 The comment invited the courts to "police explicitly" harsh contracts rather than having resort to adverse construction of language or twisted application of contract law as was the prior practice. Nevertheless, the avowed intent of the proponents of the Code in giving the courts this power was not to disturb the allocation of risk flowing from the bargaining power of the parties, but rather to prevent oppression and unfair surptise. ${ }^{15}$

The present version of section 2-302 amends the 1952 final draft so as to give the courts the alternative of modification in addition to the power

10 Uniform Revised Sales Act \& 23 (Proposed Final Draft No. 1, 1944).

11 UnIforar Commercial Code \$2-302, comment (Tent. Draft 1949). Subsection (2) also made reference to form clauses. Section 1-102(3) (f) of the 1952 official draft stated as one of the "rules of construction" that the comments could be consulted in the construction and application of the Code. In the present draft this rule was deleted from $\S 1-102$ and is found in substantially the same form in the comment to the title. The function of the comments is "to promote uniformity, to aid in viewing the Act as an integrated whole, and to safeguard against misconstruction."

12 UnIforar Commerctal CoDe $\$ 2-302$, comment (Tent. Draft 1949) provided: "Another common type of situation arising in connection with unconscionable contracts or clauses consists of cases where one party has deliberately entered into a lopsided bargain with full knowledge and awareness and has actually assented to clauses which are unconscionable in effect against him."

13 Uniforar Commerctal Code \$2-302, comment (Tent. Draft 1949).

14 Uniform Comarercial Code \$2-302, comment (Proposed Final Draft, Spring 1950), sets forth the same basic test as is found in the current version. The current comment reads: "The basic test is whether, in the light of the general commercial background and the commercial needs of the particular trade or case, the clauses involved are so one-sided as to be unconscionable under the circumstances existing at the time of the making of the contract." For the same reason, it was suggested that the words "refuse to enforce" be rephrased "to avoid the inference that it deals only with the question of specific performance." ALI, UNIFORM COMMEERCIAL CODE, may Meeting Revisions to Proposed Final Draft No. 2 (1951).

15 Uniforar CoMrmerctar Code \$2-302, comment. This goal of protecting the ordinary consumer from harsh contracts was recognized by commissions appointed by state legislatures to study the Code. See 1 N.Y. LAW Revision Commission, StudY OF THE UNIFORM CoMArERCIAI CoDE 655-61 (1955). This theme is also noted by the Pennsylvania Joint State Government Commission Report. In this report, it is stated that the section's approach may be novel to sales law but nonetheless is consistent with the resilts of decisions which have avoided harsh provisions in sales contracts by narrow construction. Pennsylvania Annotatrons to the Proposed UnIForM CoMIMERCLAL CoDE 18 (1952). 
of complete voidance of an unconscionable contract or clause. ${ }^{16}$ The determination of unconscionability remains with the court rather than the jury, ${ }^{17}$ and the time of the creation of the contract is still the crucial point at which the section's test is to be applied.18 But unfortunately, the comment to the present draft continues the so-called "basic test" which, in view of its definition of unconscionability in terms of itself, ${ }^{19}$ is an unhelpful tautology. It is significant that there was again no explicit reference to form contracts. The comment retains, in an attempt to indicate a definitional standard, illustrative cases in which courts have voided unfair bargains. ${ }^{20}$ On their face these decisions are inconclusive; with the exception of the leading equity case on unconscionable sales contracts, ${ }^{21}$ they involve disclaimers of warranty or limitations of remedy-both of which are expressly treated by other specific provisions of the Code. ${ }^{22}$ Despite the apparent overlap of

16 The 1952 draft was criticized for limiting the judicial remedy to the complete invalidation of the unconscionable clause or contract. See Note, 63 Y ALE L.J. 560, 562 (1954). This is changed by the current subsection (1), which provides that a court "may so limit the application of any unconscionable clause as to avoid any unconscionable result."

17 UnIForm CoMmercial CODE $\$ 2-302(1)$, comment 3.

18 Uniform Commercial Code §2-302(1).

19 See note 14 supra.

20 "Kansas City Wholesale Grocery Co. v. Weber Packing Corp., 93 Utah 414, 73 P.2d 1272 (1937), where a clause limiting time for complaints was held inapplicable to latent defects in a shipment of catsup which could be discovered only by microscopic analysis; Hardy v. General Motors Acceptance Corp., $38 \mathrm{Ga}$. App. 463, 144 S.E. 327 (1928), holding that a disclaimer of warranty clause applied only to express warranties, thus letting in a fair implied warranty; Andrews Bros. v. Singer \& Co., (1934 CA) 1 K.B. 17, holding that where a car with substantial mileage was delivered instead of a 'new' car, a disclaimer of warranties, including those 'implied,' left unaffected an 'express obligation' on the description, even though the Sale of Goods Act called such an implied warranty; New Prague Flouring Mill Co. v. G. A. Spears, 194 Iowa 417, 189 N.W. 815 (1922), holding that a clause permitting the seller, upon the buyer's failure to supply shipping instructions, to cancel, ship, or allow delivery date to be indefinitely postponed 30 days at a time by the inaction, does not indefinitely postpone the date of measuring damages for the buyer's breach, to the seller's advantage; and Kansas Flour Mills Co. v. Dirks, 100 Kan. 376, 164 P. 273 (1917), where under a similar clause in a rising market the court permitted the buyer to measure his damages for non-delivery at the end of only one 30 day postponement; Green v. Arcos, Ltd. (1931 CA) 47 T.L.R. 336, where a blanket clause prohibiting rejection of shipments by the buyer was restricted to apply to shipments where discrepancies represented merely mercantile variations; Meyer v. Packard Cleveland Motor Co., 106 Ohio St. 328, 140 N.E. 118 (1922), in which the court held that a 'waiver' of all agreements not specified did not preclude implied warranty of fitness of a rebuilt dump truck for ordinary use as a dump truck; Austin Co. v. J. H. Tillman Co., 104 Or. 541, 209 P. 131 (1922), where a clause limiting the buyer's remedy to return was held to be applicable only if the seller had delivered a machine needed for a construction job which reasonably met the contract description; Bekkevold v. Potts, 173 Minn. 87, 216 N.W. 790 . . (1927), refusing to allow warranty of fitness for purpose imposed by law to be negated by clause excluding all warranties 'made' by the seller; Robert A. Munroe \& Co. v. Meyer (1930) 2 K.B. 312, holding that the warranty of description overrides a clause reading 'with all faults and defects' where adulterated meat not up to the contract description was delivered."

21 Campbell Soup Co. v. Wentz, 172 F.2d 80 (3d Cir. 1948). See notes 73-77 infra and accompanying text.

22 UNIFORM COMMERCIAI CODE \& 2-316 (exclusion or modification of warranties); UNIFORM COMMERCIAI CODE $\$ 2-719$ (contractual modification or limitation of remedy). 
these sections, ${ }^{23}$ however, the operative facts of the cases cited ${ }^{24}$ suggest the general area of the draftsmen's concern.

Further understanding of the legislative intent can be gleaned from related sections in the sales article of the Code. Section 2-719, governing contractual modification or limitation of remedy, renders prima facie unconscionable a contract in which there is a limitation of consequential damages for personal injury in the case of consumer goods. ${ }^{25}$ Another application for section 2-302 is suggested by the comment to section 2-718: if an unreasonably small amount is stipulated as liquidated damages, such a provision might be stricken as unconscionable when the loss is far greater than had been anticipated. ${ }^{26}$ Although the Code has specific sections governing requirements contracts and disclaimer clauses, ${ }^{27}$ it would be myopic to read these sections independently of section 2-302. For in order to realize the full impact of section 2-302, it is essential to view it in the context of a Code policy that the rules stated shall be sufficiently broad to be adaptable to unexpected cases rather than inflexible hornbook principles which would have to be manipulated to fit the desired results in situations beyond the possibilities imagined at the time of drafting. ${ }^{28}$

During this legislative development, the scope of the section has been increased in several respects : the provision's applicability has been extended to other than form contracts; the possible narrowing effect of the early comment references to equity doctrine has been eliminated; and the judiciary has been given a choice of available remedies. It was the intention of the draftsmen that the section's future applicability be given direction by the badges of unfairness common to the illustrative cases cited in the comment. Confronted with the possible enforcement of a harsh contract or clause, these decisions had invoked sub silentio a doctrine similar to that

23 See notes 114-15 infra and accompanying text for a discussion of the statutory overlap problem.

24 See the examination of the case law development at notes 29-32, 41-62 infra and accompanying text.

25 UnIForM COMMERCIAL CODE \$2-719(3).

26 UNIFORM COMMERCIAL CODE \$2-718, comment 1. This suggestion of the comment might conflict with a literal interpretation of \$2-302. Under \$2-718 the court is directed to judge the reasonableness of the stipulation of damages clause not only at the time the contract was made but also in the light of actual harm incurred. This dual directive is authorized under $\$ 2-718$ for a court confronted with a large liquidated damages clause and a small actual loss; a court viewing the converse situation under $\$ 2-302$, being limited to construction of the contract at the time it was made, can determine the reasonableness only of the anticipated damages in ruling on the clause's unconscionability. It probably could not declare the clause unconscionable because the loss actually incurred was far in excess of the stipulated amount when judged retrospectively.

27 UNIFORM COMMMERCIAL CODE \$2-306 (output, requirements, and exclusive dealings); UNIFORM COMMIERCLAL CODE $\$ 2-316$ (exclusion or modification of warranties). 283 N.Y. LAw Revision Commission, Study of the UNIForm Commercial CoDE 2175 (1955). Professor Fulda points out the following as examples of "general clauses which permit adaptation to new conditions": \$2-103(1) (b)-“merchants must observe 'reasonable commercial standards'"; \$2-716(1) - "specific performance may be decreed where goods are unique or 'in other proper circumstances'"; \&3-511(1) - "reasonable diligence" ; \$ \$-406(1) (a)- " "good faith and due diligence" " \$ 1-203 - "obligation of good faith" ; $\$ \$ 1-204(1),(3)$ - "reasonable time," "seasonably." 
enunciated in the section. And since the legislative history affords little other insight as to the section's reach, the facts of the cited cases assume critical importance in lending some sense of definitude to the seemingly amorphous statutory provision.

\section{The CASE LAW}

\section{Background}

Judicial protection against nonfraudulent but oppressive agreements has deep roots. Centuries ago, the chancellor granted the mortgagor an equity of redemption, thereby providing him with a means of meeting his obligation and yet avoiding the absolute and drastic consequences of failure to repay on the date due..$^{28}$ The principle behind this development is evidenced in many equity decisions. ${ }^{30}$ For example, the payment of a water bill, thought to be excessive, under fear that the supply would be cut off, has been found to be coerced-the excess was recoverable. ${ }^{31}$ Equity has similarly afforded relief against surprise; thus, a buyer with special knowledge of a property's future value has been denied specific enforcement of his quick contract with an uninformed vendor. ${ }^{32}$ Such problems of economic duress and unfair surprise also arise in sales law and have been accentuated in recent years by the increasing use on the part of large industrial sellers of the standardized form contract in order to keep pace

29 Emanuel College v. Evans, 1 Ch. R. 18, 21 Eng. Rep. 494 (1625). Hanna describes the plight of the farmer-mortgagor in sixteenth-century England as follows: "In the case of a mortgage of agricultural land, under any conditions and particularly under conditions of primitive agriculture, the likelihood of quick repayment is relatively small. Early loans were not long-time loans. A succession of crop failures will prevent even the able and industrious farmer from earning anything. The loan by the mortgagee is consequently likely to be at a higher interest rate (itself a factor, tending to make repayment difficult), and is likely to extend only to a small portion of the value of the land. Where the exact date of tender of loan is insisted upon, forfeiture may be occasioned by accident, flood, or similar mischance . . . . It is then this type of pressure and apparent hardship which induces the chancellors to disregard the strict terms of the mortgage conveyance and recognize a tender after the 'law day' as sufficient to redeem the land from the mortgagee. Thus is created the sequity of redemption." HANNA, CASES ON Security 658-59 (3d ed. 1959).

30 E.g., Lonergan v. Buford, 148 U.S. 581, 589-91 (1893) (balance due on purchase of cattle paid under duress; held recoverable) ; Butler v. Duncan, 47 Mich. 94, 10 N.W. 123 (1881) (devisee forced by economic circumstances to sell his expectancy "for a song"); Niggeler v. Maurin, 34 Minn. 118, 24 N.W. 369 (1885) (mortgagor conveyed equity of redemption under pressure of financial difficulties). Much of this development is reviewed by Mr. Justice Frankfurter, dissenting, in United States v. Bethlehem Steel Corp., 315 U.S. 289, 326-30 (1942). The principle was also operative in early English statutes. See Amendment of the Law, 1705, 4 \& 5 Anne c. 3, \$\$ 12, 13; Actions on Breaches on Bonds Act, 1697, 8 \& 9 Will. 3, c. 11, \$8. Both statutes dealt with penal bonds and provided that the obligee was allowed to have execution only for the actual damages suffered by him.

31 Westlake \& Button v. City of St. Louis, 77 Mo. 47 (1882).

32 Banaghan v. Malaney, 200 Mass. 46, 85 N.E. 839 (1908). See Forman v. Gadouas, 247 Mass. 207, 142 N.E. 87 (1924), where, although the court recognized the same principle, the evidence was insufficient to support the master's findings that the woman vendor parted "with her home and only means of income under a contract improvidently, unconscionably and hastily made, when she . . . acted without independent advice." Id. at 210,142 N.E. at $88-89$. 
with the mass production of goods and services. ${ }^{33}$ Such pad contracts present the ordinary consumer with a Hobson's choice, extended by a seller with superior bargaining power who has the advantage of unilaterally setting most of the terms incident to the buyer's remedies for dissatisfaction. From the civil law this phenomenon is appropriately designated the contract of adhesion ${ }^{34}-\mathrm{a}$ bete noire to which the buyer affixes his signature after bargaining only over the filled-in terms. In a few areas, such as insurance ${ }^{35}$ and dealer franchise contracts, ${ }^{36}$ abuse of the standardized contract practice became so flagrant that legislative action was taken to protect the adhering party. But in most of the day-to-day sales transactions, the courts, saddled with a body of well-defined contract law which holds a party bound by his signature, are caught in the dilemma of either enforcing the harsh contract or incurring the accusation that they are violating "freedom of contract." 37

In such a posture, some courts, perceiving no freedom in such contracts, have resorted to various formalistic devices to avoid enforcement..$^{38}$

33 Llewellyn, Book Review, 52 Harv. L. REv. 700, 701 (1939).

34 This term was introduced into the American common law in reference to insurance contracts where the insured was said to have merely "adhered" to the predetermined terms of the contract. Patterson, The Delivery of a Life Insurance Policy, 33 HaRv. I. REv. 198, 222 (1919). However, the development of the concept in American contract law is primarily the product of scholars with a civil-law background. See Ehrenzweig, Adhesion Contracts in the Conflict of Lazws, 53 CouUM. L. REv. 1072, 1088-89 (1953); Kessler, Contracts of Adhesion-Some Thoughts About Freedom of Contract, 43 CoLUM. L. REv. 629 (1943).

35 Insurance companies have been compelled by legislatures to insert particular clauses into their contracts. VANCE, INSURANCE 59 (3d ed. Anderson 1951).

${ }^{36}$ These standardized contracts contained exculpation. and termination clauses which the courts continued to enforce despite their obvious one-sidedness. See, e.g., Bushwick-Decatur Motors, Inc. v. Ford Motor Co., 116 F.2d 675, 677 (2d Cir. 1940) ; Ford Motor Co. v. Kirkmyer Motor Co., 65 F.2d 1001, 1006 (4th Cir. 1933). See also S. B. McMaster, Inc. v. Chevrolet Motor Co, 3 F.2d 469, 473-75 (E.D.S.C. 1925) ; Kessler, Auto Dealer Franchises: Vertical Integration by Contract, 66 Y L.J. 1135, 1155 (1957). This state of affairs was remedied by federal legislation which gave the dealer a cause of action in the federal courts for failure of a manufacturer "to act in good faith in performing or complying with any of the terms or provisions of the franchise, or in terminating . . the franchise with said dealer." 70 Stat. 1125 (1956), 15 U.S.C. \$ 1222 (1958). Similar legislation is found in many of the states. See, e.g., Minn. Stat. Ann. \$168.27 (1960); WIs. Stat. § 218.01 (1957). See generally Note, 70 HARv. L. REv. 1239 (1957). A similar abuse in the use of forms led Congress to intervene regarding common carrier liability to customers. Interstate Commerce Act $\$ 20,24$ Stat. 386 (1887), as amended, 49 U.S.C. $\$ 20$ (1958).

37 The classical theory of contract is that "unimited freedom of making promises was a natural right." Pound, Liberty of Contract, 18 YALE L.J. 454, 456 (1909). Compare Sir George Jessel's famous statement in Printing \& Numerical Register Co. v. Sampson, I.R. 19 Eq. 462, 465 (1875): "[I]f there is one thing more than another public policy requires it is that men of full age and competent understanding shall have the utmost liberty of contracting, and that their contracts when entered into freely and voluntarily shall be held sacred and shall be enforced by Courts . . . . You have the paramount public policy to consider-that you are not likely to interfere with the freedom of contract." But see Kessler, supra note 34, at 642, where the argument is advanced that "freedom of contract must mean different things for different types of contracts. Its meaning must change . . with the degree of monopoly enjoyed by the author of the standardized contract." For a case illustrating these conflicting pulls, see Bushwick-Decatur Motors, Inc. v. Ford Motor Co., 116 F.2d 675, 677 (2d Cir. 1940).

38 See notes 41-62 infra and accompanying text. 
But numerous others adhere to the principle of contractual freedom and, notwithstanding the harshness, hold that a party who enters a contract for fair consideration and in compliance with the other common-law requirements necessary to the formation of a binding contract is not entitled to relief. $^{39}$ Because of these countervailing forces of opinion, the express holdings of the cases are often irreconciliable. ${ }^{40}$ But in certain of the more common unconscionable situations a pattern of judicial treatment can be discerned by focusing not so much on the results of the cases as on the relevant facts emphasized by the courts in reaching their decisions.

\section{Indirect Avoidance of Unconscionability}

The ubiquitous disclaimer of warranty ${ }^{41}$ in the manufacturers' standard contract form has given rise to a considerable volume of litigation. The proffered justifications for the widespread use of a "guarantee" which guarantees limited liability or a "warranty" which disclaims warranties are the desirability of industry's selection and control of risks in the marketing of its products and the necessity for business to shield itself from the "irrational factor" present in a jury trial.42 Decisions involving these disclaimers evidence a dissatisfaction with the unfairness resulting from this commercial practice. Thus, when faced with a defense based on a printed disclaimer, the courts have often found failure of consideration ${ }^{43}$ or lack of

39 See, e.g., Siegelman v. Cunard White Star, Ltd., 221 F.2d 189, 198 (2d Cir. 1955) (summary judgment granted on grounds of time limit clause of form contract ticket); Shafer v. Reo Motors, Inc., 108 F. Supp. 659 (W.D. Pa. 1952), aff'd, 205 F.2d 685 (3d Cir. 1953) (summary judgment granted since disclaimer precluded action for negligence).

40 Compare Dimoff v. Ernie Majer, Inc., 347 P.2d 1056 (Wash. 1960) (party bound by manufacturer's standard disclaimer), with McCown v. Jennings, 209 S.W.2d 408 (Tex. Civ. App, 1948) (identical warranty interpreted to allow recovery). On "waiver of defenses," compare Quality Fin. Co. v. Hurley, 337 Mass. 150, 148 N.E.2d 385 (1958), with Refrigeration Discount Corp. v. Haskew, 194 Ark. 549, 108 S.W.2d 908 (1937).

41 The manufacturer's standard disclaimer is in effect a limitation of remedy to replacement of defective parts under the set terms; the total exclusion of all warranties is a rarity. The uniform warranty of the Automobile Manufacturers' Association runs as follows: "It is expressly agreed that there are no warranties, express or implied, made by either the dealer or the manufacturer on the motor vehicle, chassis, or parts furnished hereunder except as follows: The manufacturer warrants each new motor vehicle (including original equipment placed thereon by the manufacturer except tires), chassis or parts manufactured by it to be free from defects in material or workmanship under normal use and service. Its obligation under this warranty being limited to making good at its factory any part or parts thereof which shall, within ninety $(90)$ days after delivery of such vehicle to the original purchaser or before such vehicle has been driven 4,000 miles, whichever event shall first occur, be returned to it with transportation charges prepaid and which its examination shall disclose to its satisfaction to have been thus defective; this warranty being expressly in lieu of all other warranties expressed or implied, and all other obligations or liabilities on its part, and it neither assumes nor authorizes any other person to assume for it any other liability in connection with the sale of its vehicles." Quoted in Henningsen v. Bloomfield Motors, Inc., 32 N.J. 358, 367, 161 A.2d 69, 74 (1960).

42 Kessler, supra note 30 , at 631-32.

43 See, e.g., Laitner Plumbing \& Heating Co. v. McThomas, 61 S.W.2d 270 (Kansas City Ct. App. 1933); Myers v. Land, 314 Ky. 514, 235 S.W.2d 988 (1951). The doctrine of consideration can be easily manipulated by the judges to achieve practical results. See Sharp, Pacta Sunt Servanda, 41 Colum. I. Rev. 783, 794-98 (1941). 
mutual assent 44 to circumvent the effect of the disclaimer. In addition, the rules of offer and acceptance, ${ }^{45}$ the inadequacy of the pleadings, ${ }^{46}$ and the nebulous norms of public policy ${ }^{47}$ have on occasion been used to obtain the desired results. The courts also have interpreted the disclaimer in such a manner as to exclude express warranties only; ${ }^{48}$ equally common has been resort to a unique interpretation of the clause which, though contrary to accepted canons of construction, has the intended consequence of eviscerating the disclaimer. ${ }^{49}$

Although these decisions are often clothed in a formal contract doctrine, certain salient facts constantly reappear to influence, if not determine, the courts' holdings. The importance of a formidable document with fine print disclaimers which the buyer never noticed-and much less understood-is frequently underscored by the courts in denying defenses based on the fine print. ${ }^{50}$ The favored party has almost always drafted the form contract clause on which his defense is based; ${ }^{51}$ likewise, the parties are often of unequal commercial experience. ${ }^{52}$ This recurrent factual pattern

44 See, e.g., Joseph v. Sears Roebuck \& Co., 224 S.C. 105, 117, 77 S.E.2d 583, 589 (1953) ; Reliance Varnish Co. v. Mullins Lumber Co., 213 S.C. 84, 91, 48 S.E.2d 653, 658-59 (1948).

45 Celanese Corp. of America v. John Clark Industries, Inc., 214 F,2d 551 (5th Cir. 1954) (a battle of forms; held that the acknowledgment order form, containing the disclaimer, was subsequent to the formation of the contract).

46 Davis Motors, Dodge \& Plymouth Co. v. Avett, 294 S.W.2d 882, 887 (Tex.

Civ. App. 1956) (disclaimer provision improperly pleaded under local rules).

47 See, e.g., Ozark Dam Constructors v. United States, $130 \mathrm{Ct}$. Cl. 354, $127 \mathrm{~F}$. Supp. 187 (1955) ; Nashua Gummed \& Coated Paper Co. v. Noyes Buick Co., 93 N.H. 348, 351, 41 A.2d 920, 922 (1945) (dictum).

48 See, e.g., Bekkevold v. Potts, 173 Minn. 87, 89, 216 N.W. 790, 791 (1927)

("[implied warranty] arises independently and outside of the contract"); Meyer v. The Packard Cleveland Motor Co., 106 Ohio St. 328, 140 N.E. 118 (1922); Jarnot v. Ford Motor Co., 191 Pa. Super. 422, 156 A.2d 568 (1959).

49 Hambrick v. Peoples Mercantile \& Implement Co., 228 Ark. 1021, 311 S.W.2d 785 (1958); Diamond Alkali Co. v. Godwin, 100 Ga. App. 799, 112 S.E.2d 365 (1959), aff'd, 215 Ga. 839, 114 S.E.2d 40 (1960) ; Stryker v. Rusch, 8 App. Div. 2d 244, 187 N.Y.S.2d 663 (1959); Meehan v. Kaveny Bros. Oil Co., 27 N.J. Super. 547, 99 A.2d 841 (Super. Ct. 1953); McCown v. Jennings, 209 S.W.2d 408 (Tex. Civ. App. 1948). 50 Celanese Corp. of America v. John Clark Industries, Inc., 214 F.2d 551 (5th Cir. 1954) (printed acknowledgment order form); Hambrick v. Peoples Mercantile \& Implement Co., supra note 49 ("printed in small type"); Myers v. Land, $314 \mathrm{Ky}$. 514, 235 S.W.2d 988 (1951) ("long and formidable document"); Joseph v. Sears Roebuck \& Co., 224 S.C. 105, 77 S.E.2d 583 (1953) ("printed book of instructions" limiting liability); Reliance Varnish Co. v. Mullins Lumber Co., 213 S.C. 84, 48 S.E.2d 653 (1948) ("so located as to easily escape attention"; "stipulation in fine print").

61 See Ozark Dam Constructors v. United States, 130 Ct. Cl. 354, 127 F. Supp. 187 (1955) ; Myers v. Land, supra note 50; Joseph v. Sears Roebuck \& Co., supra note 50 . Naturally, the drafter of the form contract is the party who pleads the disclaimer clause as a defense. Cf. Marion Mach., Foundry \& Supply Co. v. Cincinnati Coffin Co., 162 Ohio St. 455, 124 N.E.2d 132 (1955), where the purchaser was bound by the exclusive remedies set forth in a purchase order form which he had prepared and submitted to the manufacturer.

52 The disclaimer usually arises as a defense when an average customer is suing a large company. See, e.g., Hambrick v. Peoples Mercantile \& Implement Co., 228 Ark. 1021, 311 S.W.2d 785 (1958) (buyer of cotton-picking machine v. farm implement company); Joseph v. Sears Roebuck \& Co., 224 S.C. 105, 77 S.E.2d 583 (1953) (buyer of pressure cooker v. department store). 
indicates that the courts are more concerned with the ability of the buyer to comprehend the meaning of the disclaimer and its effect on his rights than with the construction obviously intended by the manufacturer. The importance of such factors is not overlooked even by those courts which hold that the disclaimer precludes the buyer's recovery. Although many courts enforce "unbargained for" disclaimers which immunize the seller from liability for his negligence or defective merchandise, they often have thought it necessary to offer other grounds in support of their decisions and have been unwilling to rest enforcement of the clause solely on the finding of a signed contract. ${ }^{53}$ These additional reasons emphasize that the party being "oppressed" authored the form contract or that the expertise of the parties was equal or favored the one seeking to avoid the harsh clause. ${ }^{54}$ Moreover, in cases not affording any doctrinal excuse for nonenforcement, some courts have displayed a distaste in being constrained to recognize a defense based on a clause which so offends "the sense of justice of the court" 55 and have expressed hope that the legislature will relieve them of such a duty. ${ }^{56}$

Similar observations can be made in situations where the purchaser has signed a conditional sales contract form which is usually supplied to the seller by a finance company. Such contracts invariably contain a "waiver of defenses" whereby the buyer surrenders, in any action brought by the finance company to collect on the contract, all defenses which he could have raised against the seller. Even if the buyer reads and fully understands the clause, the unavailability of conditional sales financing on terms other than those offered forces him to accept. Where the clause has been declared "contrary to public policy," the courts have not infrequently noted the "long closely printed agreement form" 57 supplied by the enforcing party and the likelihood that the waiver clause was overlooked by the customer. On the other hand, some courts permitting the finance company to recover have

53 Alaska Pac. Salmon Co. v. Reynolds Metals Co., 163 F.2d 643 (2d Cir. 1947) (letter specifically called attention to conditions in contract); Norton Buick Co. v. E. W. Tune Co., 351 P.2d 731 (Okla. 1960) (buyer's request for repairs was always honored by dealer); Magar v. Lifetime, Inc., $187 \mathrm{~Pa}$. Super. 143, 144 A.2d 747 (1958) (buyer failed to carry burden of proof). But see Shafer v. Reo Motors, Inc., 108 F. Supp. 659 (W.D. Pa. 1952), aff'd, 205 F.2d 685 (3d Cir. 1953); Christie v. Thomasville Sales Co., 98 Ga. App. 151, 105 S.E.2d 254 (1958); Dimoff v. Ernie Majer, Inc., 347 P.2d 1056 (Wash. 1960).

54 Whane Supply Co. v. Gregory, 291 S.W.2d 835 (Ky. 1956) (buyer's "Iong period of use and his knowledge of machinery of the type in question") ; Richardson v. Waterite Co., 169 Neb. 263, 99 N.W.2d 265 (1959) (both parties were expert in the field) ; Marion Mach., Foundry \& Supply Co. v. Cincinnati Coffin Co., 162 Ohio St. 455, 124 N.E.2d 132 (1955).

55 Hall v. Everett Motors, Inc., 165 N.E.2d 107, 109 (Mass. 1960).

50 Moss v. Gardner, 228 Ark. 828, 832, 310 S.W.2d 491, 493 (1958) ("If manufacturers continue to resort to such fine print on the back of the contract, it may be that a person buying an expensive piece of machinery will have to take a lawyer with him."); Hall v. Everett Motors, Inc., sipra note 55 (citing UNIFORA CoMMERCIAL CODE \$2-316, court indicated that a case arising under the Code would not be controlled by precedent as was the instant case).

57 Quality Fin. Co. v. Hurley, 337 Mass. 150, 148 N.E.2d 385 (1958) ("long closely printed agreement form") ; Industrial Loan Co. v. Grisham, 115 S.W.2d 214 (Mo. App. 1938) (buyer filled in blanks). 
emphasized the maturity and intelligence of the purchaser in support of their decisions. ${ }^{58}$ The relevance of such considerations is difficult to comprehend unless the court is not in fact basing its decision solely on the expressed grounds but is also vitally concerned with what the contract meant to both parties at the time it was made.

A body of cases involving time limitations which require that "any dispute or claim . . . must be made in writing within ten working days after the receipt of the goods" are likewise based on unarticulated premises. The established rule is that time limits beyond which no action may be maintained by the buyer are valid for "patent" defects, ${ }^{59}$ but that when such defects are labelled "latent," the rules of reasonableness determine the period within which suit may be brought. ${ }^{60}$ Using a process not unlike that employed in the disclaimer and waiver cases, the courts are likely to label a defect "latent" to circumvent an explicit contractual time limitation clause buried in the printed form supplied by the seller. Their decisions often evidence an awareness of the meaning which the buyer would have been likely to have placed upon the provision had he read it - that is, that its pervasive terms applied only to reasonably noticeable defects. ${ }^{61}$

The outcome in many of these cases which void a harsh clause is not compelled by the contract doctrine on which it is pegged. Certainly, the language of some of the "ambiguous" disclaimers does not support the resulting judicial interpretation; and it is not inconceivable that a "waiver of defenses" clause, unnoticed in a "long closely printed form," would be declared consistent with public policy., Likewise, a provision clearly requiring that the seller must be notified of all defects in the goods within a specified time does not by its terms exclude hard-to-discover defects. Although these decisions sound in traditional contract doctrine, thereby preserving the "myth that the law of contracts is of one cloth," 62 the results are merely a hodgepodge of borderline cases unless one looks to what the courts are in fact doing.

58 See, e.g., Refrigeration Discount Corp. v. Haskew, 194 Ark. 549, 108 S.W.2d 908 (1937) (court noted that purchaser was a grown man and a teacher); HartfordConnecticut Trust Co. v. Clark-Barone Co., 21 Conn. Supp. 368, 154 A.2d 883 (Super. Ct. 1959) ("buyer and seller stood on equal footing"). But see Jones v. Universal CIT Credit Corp., 88 Ga. App. 24, 75 S.E.2d 822 (1953); Commercial Credit Corp. v. Biagi, 11 Ill. App. 2d 80, 136 N.E.2d 580 (1956) (recovery allowed solely on ground of a signed conditional sales agreement).

59 E.g., Oliver Farm Equip. Sales Co. v. Neely, 50 Ga. App. 231, 177 S.E. 606 (1934); Truscon Steel Co. v. Fuhrman \& Schmidt Brewing Co., $327 \mathrm{~Pa}$ 10, 192 Atl. 679 (1937).

60 W. F. Main Co. v. Fields, 144 N.C. 307, 56 S.E. 943 (1907) ; Kansas City

Wholesale Grocery Co. v. Weber Packing Corp., 93 Utah 414, 73 P.2d 1272 (1937).

61 See, e.g., Kansas City Wholesale Grocery Co. v. Weber Packing Corp., 93 Utah 414, 73 P.2d 1272 (1937) ; National Grocery Co. v. Pratt-Low Preserving Co., 170 Wash. 575, 17 P.2d 51 (1932) (formal contract sent by seller "contained on its back, closely typewritten" a time limit clause); Note, The Sales Contract as a Linitation of the Privilege of Inspection, 35 Colvar. L. REv. 64 (1935). But cf. Walter Pratt \& Co. v. W. C. Morris \& Co., 27 Ky. L. Rep. 1035, 87 S.W. 783 (Ct. App. 1905) (buyer was an "experienced druggist" and knew whether goods could be examined within the time specified).

62 Kessler, supra note 34 , at 634 . 
In terms of presaging the application of section 2-302, the reasons expressed in such decisions are obviously less important than the common factors behind the holding. It is most significant that the vast majority of these cases involve form contracts in which the crucial provision is printed in type sufficiently minute to deemphasize its importance and discourage a careful reading. ${ }^{63}$ This does not mean, of course, that the presence of a printed form contract per se determines the outcome; it does indicate that the vast majority of such "agreements" occur in circumstances inimical to genuine dickering over certain printed clauses. When handed a printed form to sign, the buyer will ordinarily concern himself only with the provisions to be filled in-those for which he has actually bargainedand will overlook or ignore the clauses governing the remedies available to him in the event the merchandise proves defective. To the ordinary customer, the filled-in terms constitute the transaction. Even if the deceptively termed "warranty" or the printed "waiver" were expressly called to his attention, it could hardly be supposed that he would be made cognizant of what he is sacrificing. ${ }^{64}$ The chances are remote indeed that a buyer, quickly skimming the fine print, will test the meaning of the clause (if it means anything at all to him) in the context of potential fact situations. Will he realize that the "warranty" seeks to preclude recovery for personal injuries if his new automobile should suddenly veer off the highway into a wall? ${ }^{65}$ Something more than simply referring a customer to legalisms in a printed form must be done to inform him of his rights-or lack of them-under the contract. 68

This analysis, centered on the range of understanding between the contracting parties, is more sharply exemplified in cases dealing with specification of damages clauses. Generally, courts will not enforce a specification of damages clause if it is a "penalty." Although not all victims of an improvident bargain are protected by this rule, the courts display a willingness to protect those who have "entered into an improvident agreement to pay an exorbitant sum of money in the event of . . . default in some respect which does not, in fact, cause anything like equivalent damage to the other party." ${ }^{67}$ If the claiming party has incurred no dam-

63 For a collection of the various means of making important clauses illegible, see Mellinkoff, How To Make Contracts Illegible, 5 Stan. L. Rev. 418 (1953).

64 For a study of the different meanings which words have to different people, see Probert, Law and Persuasion: The Language-Behavior of Laveyers, 108 U. PA. L. Rev. 35 (1959). See generally KorzybSkI, ScIENCE AND SANIty (4th ed. 1958); Ogden \& Richards, The Meaning of Meaning (5th ed. 1938).

65 See Henningsen v. Bloomfield Motors, Inc., 32 N.J. 358, 161 A.2d 69 (1960).

${ }^{86}$ An example is UNIFORM COMMERCIAL CODE $\$ 2-316$, which sets up explicit rules governing enforceable disclaimers: to exclude warranties of merchantability the language must mention the term "merchantability"; a warranty of fitness may be excluded by general language, but the exclusion must be written and conspicuous. If the disclaimer is in the body of the form, "conspicuous" means that it must be in larger or other contrasting type, or of a different color. UNIFORM CoMMERCIAL Cone $\S 1-201(10)$. Such a test would not be satisfied in most current standard manufacturers' warranties.

67 Burnett v. Nolen, 336 Ill. App. 376, 379, 84 N.E.2d 155, 156 (1949). 
ages, the clause has usually been held to be a "penalty." ${ }^{88}$ This so-called "no harm" rule ${ }^{69}$ is merely a judicial expression for denying recovery in a situation where the parties obviously did not intend the stipulated relief to be effective. Although it has been suggested that an equitable result could be reached by manipulation of the "reasonable endeavor to ascertain actual damages" requirement for a liquidated damage clause, ${ }^{70}$ the courts have been more inclined to withhold their imprimatur on the express grounds that in such a case no actual damage has been incurred. ${ }^{71}$ By adopting this approach, the tribunal is forced to acknowledge that the parties understood themselves to be setting a fixed figure which would be applicable in the event damages occurred. And by holding that, despite a technical breach, the liquidated damage provision becomes operative only in the event of actual damage, these cases offer an analogy to the tack which a court applying section 2-302 should take in deciding the issue of unconscionability. ${ }^{72}$

\section{The Campbell Soup Case}

A leading unconscionable sales contract case in equity, Campbell Soup Co. v. Wentz, ${ }^{73}$ offers an excellent illustration of the contrasting techniques, direct and indirect, utilized to police harsh contracts. The case involved a grower-canner form contract for the sale at a fixed price of all the Chantenay red-cored carrots to be grown on fifteen acres of the Wentz farm during the 1947 season. The agreement was the standard type used by Campbell in dealing with farmers; it contained numerous fine-print clauses favorable to the company. Among the more significant were these: the carrots were to have their stalks cut off and be in clean sanitary bags or other containers approved by Campbell; the company had the right to refuse carrots in excess of twelve tons to the acre; grower promised not to sell carrots to any other person (carrots rejected by Campbell were excepted from this requirement), and he further agreed to permit no one else to grow carrots on his land; liquidated damages of fifty dollars per acre were set for any breach by the grower while no damages were stipulated in the event of a breach by Campbell. ${ }^{74}$ The provision thought to be "hardest" gave Campbell the right to reject any carrots which it was unable

68 See, e.g., Priebe \& Sons, Inc. v. United States, 332 U.S. 407 (1947); Massman Constr. Co. v. City Council, 147 F.2d 925 (5th Cir. 1945); Pinta v. Kral, 285 Ill. App. 232, 1 N.E.2d 876 (1936). But see McCarthy v. Tally, 46 Cal. 2d 577, 586, 297 P.2d 981, 987 (1956).

69 Comment, Liquidated Damages and the "No-Harm" Rule, 9 StAN. L. Rev. 381 (1957).

70 Id. at $385-86$.

71 See note 68 supra.

721 N.Y. Law Revision Commission, Study of the Uniform Comarerciat Code 655-56 (1955).

73172 F.2d 80 (3d Cir. 1948). For a critical analysis of the decision, see Note, Grower-Camer Agreements: An Abuse of Mass Standardized Contracts, 58 YALE L.J. 1161 (1949).

$74172 \mathrm{~F} .2 \mathrm{~d}$ at 83. 
to handle and use either because of any labor dispute or because of any circumstance beyond the control of Campbell. Under this clause, if the demand for its products should decrease and production consequently fall off, Campbell could refuse delivery of the carrots and force the farmer into an unfavorable market. ${ }^{75}$

After the contract was signed, the market price trebled the fixed contract price and the farmer refused to perform. Campbell sued in equity for specific performance. The lower court denied relief on the grounds that Chantenay red-cored carrots, although scarce, were not unique-an indirect means of avoiding enforcment of the contract. ${ }^{76}$ In contrast, the Third Circuit rejected the district court's application of the "unique" requirement and based affirmance expressly on the unconscionability of the contract, which it found "drawn by skillful draftsmen with the buyer's interest in mind" and consequently "one-sided." 77

The methodology of this case is significant in that it affords the courts at law a precedent for expressly policing unconscionable contracts; it illustrates the approach anticipated by the framers of section 2-302. But a careful application of the section would not produce the same result. ${ }^{78}$ Although the Third Circuit relieved the farmer of an unprofitable deal, it also prevented Campbell from obtaining its carrots at the preseason bargained contract price on which it had relied. It reached this result by declaring the entire contract unconscionable because of the one-sidedness of several fine print clauses which were not in issue, inasmuch as they admittedly did not prevent an otherwise binding contract from arising. ${ }^{79}$ Under section 2-302, a better balance can be struck, for a court has the alternative of eliminating only the unconscionable clauses and enforcing the remainder of the contract. ${ }^{80}$ In this way, the bargain to sell carrots at a set price is given effect without regard to the fact that it has turned out to be very profitable for only one of the parties.

Section 2-302 faces this problem by directing the court's attention to the time at which the contract was made. ${ }^{81}$ Future planning, dependent upon the stability of long range contracts, is not upset by the section's provisions. When the contract suddenly becomes advantageous to one of the parties, it is still an enforceable bargain as long as neither "unfair

75 Id. at $83 \&$ n.11. It is likely that any inability on the part of Campbell to use the carrots would have been caused by weakened demand-"a circumstance beyond the control of Campbell." Thus, the farmer had no protection in the event of a decline in the market, although Campbell was covered if the market price rose.

7675 F. Supp. 952 (E.D. Pa. 1948).

77172 F.2d at 83.

78 Note, however, that a different result is not mandatory. If a court should find that the practice of making harsh contracts can be eliminated only by striking the entire contract, this maximum remedy remains available under UNIFORM COMMARRCIAL CODE $\$ 2-302(2)$, comment.

79 Campbell was bound to accept the carrots which did in fact conform to the specifications set forth in the contract, provided, of course, that production was not curtailed.

80 See note 16 supra and accompanying text.

81. UnIForm CoMmercial Code $\$ 2-302(1)$. 
surprise" nor "economic duress" was evident at the time of its creation. The contract may conceivably fall hard upon one party but section 2-302 was not intended to void every unprofitable venture of the market place. If the section were extended to encompass all such agreements, no one could rely on what he naturally hopes to be a profitable bargain when he enters into it.

A possible conflict with the underlying rationale of the section-to avoid relief from harsh contracts-is posed by the profitable bargain which reaches gross proportions. It is conceivable that external factors may so affect the contract that the extent of the benefit to one party was never remotely contemplated at the time the contract was made. It is also possible that economic circumstances coerced a party into the only agreement possible at that moment-a moment when his immediate financial needs had to be satisfied and the other party was the only person available who could do so. In such cases, a court might be inclined to modify the contract to approximate more nearly that which the parties could have reasonably anticipated or demanded, on the grounds that to allow a grossly excessive profit or an unreasonably lengthy contract period would be unconscionable. This approach would still uphold the profitable bargain within reasonable limits. ${ }^{82}$

\section{Civil Law Development}

The problems posed by the standardized mass contract are not peculiar to the common law. In fact, it was civil-law scholars who first singled out contracts of adhesion (contrats d'adhesion) as an area of contract law badly in need of adjustment. ${ }^{83}$ At the turn of the century, Saleilles, the originator of the term, asserted that standardized form contracts partake more of the nature of statutes promulgated by businessmen and their counsel than of mutually bargained agreements. ${ }^{84}$ Because of the early and continued attention given such contracts, the civil law experience is valuable in anticipatirg the future scope of section 2-302.85

Both the German and the French systems treat the "unbargained for" contract with broad flexible provisions similar to the unconscionability concept of the Uniform Commercial Code. Article 138 of the German Civil Code takes both a general ${ }^{86}$ and a specific ${ }^{87}$ approach to harsh contracts

$82 C f$. note 67 supra and accompanying text.

83 Saleilles, DE LA Declaration DE Volante 229-30 (1901); see Prausnitz, The Standardization of Commercial Contracts in English and Continental LAw (1937); Kessler, supra note 34. See also Ehrenzweig, supra note 34.

842 Planiol, Civil Law Treatise No. 972a (1959); Prausnitz, op. cit. supra note 83 , at 122 .

85 This value was recognized in the 1 N.Y. LAw Revision Commission, Study OF THE UNIFORM COMMERCIAL CODE 97-99 (1955). For a discussion of the advantages of a comparative law study in construing the entire code, see Schlesinger, The Uniform Conmercial Code in the Light of Comparative Law, 1 INTER-AM. L. REV. 11 (1959).

86 BürGerliches Gesetzbuch \$138, para. 1 (Ger. 19th ed. Palandt 1960) : "Ein Rechtsgeschäft, das gegen die guten Sitten verstösst, ist nichtig." [A legal transaction that is against good morals is void.]

87 BürGerLICHes GesetzBUCH \$138, para. 2 (Ger. 19th ed. Palandt 1960): "Nichtig ist insbesondere ein Rechtsgeschäft, durch das, jemand unter Ausbeutung 
which are against good morals (gegen die guten Sitten), while article 242 imposes upon the contracting parties a specific duty to act according to the requirements of good faith, with due regard to ordinary usage, ${ }^{88}$ thus giving the aggrieved party a defense. In addition, article 826 allows a suit for damages if the contractual language was intentionally contrary to gute Sitten. ${ }^{89}$ The French doctrine of abus des droits, like its German counterpart, has been used both as a shield and a sword. ${ }^{90}$ Where the doctrine is invoked as a defense, it is generally believed that its basis is derived from the modern theory of Josserand that "every Code article or other statute creating a right must be interpreted as limiting the exercise of such right to the objects for which it was created." ${ }^{21}$ That principle's broad compass is illustrated by articles $1131^{92}$ and $1133^{93}$ of the French Civil Code, which make void all obligations contrary to good morals (bonnes moeurs) and public order (ordre public). In addition to these general code rules governing contracts, the civil-law scholars have taken a similar approach to contrats d'adhesion in their treatises. ${ }^{94}$

Although these principles might seem to give the civil-law courts dangerously extensive discretion, experience has shown that they have been applied with caution and have not upset the stability of commercial trans-

der Notlage, des Leichtsinns oder der Unerfahrenheit eines anderen sich oder einem Dritten für eine Leistung Vermögensvorteile versprechen oder gewähren lässt, welche den Wert der Leistung dergestalt ïbersteigen, dass den Umständen nach die Vermögensvorteile in auffälligem Missverhältnisse zu der Leistung stehen." [In particular, a legal transaction is void whereby a person, exploiting the difficulties, indiscretion or inexperience of another, causes to be promised or granted to himself or to a third party for a consideration pecuniary advantages that exceed the value of the consideration to such an extent that, having regard to the circumstances, the disproportion is obvious.]

88 Bürgerliches Gesetzbuch $\$ 242$ (Ger. 19th ed. Palandt 1960) : "Der Schuldner ist verpflichtet, die Leistung so zu bewirken, wie Treu und Glauben mit Rücksicht anf die Verkehrssitte es erfordern." [The debtor or promisor is bound to effect the performance according to the requirements of good faith, with due regard to ordinary usage.]

89 Bürgerliches Gesetzbuch $\$ 826$ (Ger. 19th ed. Palandt 1960): "Wer in einter gegen die guten Sitten verstossenden Weise einem anderen vorsätalich Schaden zufiigt, is dem anderen zum Ersatze des Schadens verpflichtet." [A person who intentionally causes damage to another in a manner contrary to good morals is bound to compensate the other for the damage.]

90 Schlesinger, Comparative Law 376 (2d ed. 1959). When used as a cause of action, it is supported by article 1382 of the French Civil Code, which provides that "every act of a person which causes damage to another obliges the person through whose fault the damage occurred to repair it." Translated in ScHLESINGER, op. cit. supra at 49 n.10.

01 Schlesinger, op. cit. supra note 90 , at 376.

92 CoDe CIvIL art. 1131 (Fr. 58th ed. Dalloz 1959) : "L'obligation sans cause, ou sur une fausse cause, ou sur une cause illicite, ne peut avoir aucun effet." [An obligation without cause, or one based on a false or illicit cause, has no effect.]

93 CoDE Crvn art. 1133 (Fr. 58th ed. Dalloz 1959): "La cause est illicite, quand elle est prohibée par la loi, quand elle est contraire aux bonnes moeurs ou a l'ordre public." [A cause is illicit when it is prohibited by law or when it is contrary to good morals or the public order.]

94 Planiol, op. cit. supra note 84, at No. 972a; SAzetules, op. cit. supra note 83, at 229-30. 
actions. ${ }^{95}$ Under the German practice, the courts will not apply the doctrine of gute Sitten unless the party seeking its application proves that his opponent has been exploiting his difficulties, indiscretion, or inexperience (der Notlage, des Leichtsinns oder der Unerfahrenheit). ${ }^{96}$ In passing upon these prerequisites, the German courts weigh the disparity of experience between the parties to determine whether an intelligent choice was possible under the circumstances, and, if so, what the parties understood the nature of their choice to be. ${ }^{97}$ In both the French and the German systems, the mere fact of a disproportionate bargain is not recognized as sufficient grounds for setting aside the contract. ${ }^{98}$ In balancing the experience of the parties, an inquiry comparable to that suggested under section 2-302 must be made-the courts focus on the relative positions of the particular parties at the time the contract was made to determine how the contract was formed. ${ }^{99}$

Several opinions of the German Reichsgericht show striking similarity to those of our own courts regarding the factors considered relevant in determining the enforceability of allegedly unfair contracts. The onesidedness of the form contract and the insignificance of the printed provision which exempts the maker from liability are particularly important. ${ }^{100}$ But, in addition, the continental courts have noted the effect of the utilization of a particular standard form on an industry-wide basis: ${ }^{101}$ in this instance, the element of free choice by the purchaser is precluded regardless of his awareness of the terms of the contract or their meaning. Such a factor is seldom alluded to by American courts, ${ }^{102}$ although it would certainly appear to be a relevant factor in examining a contract for unconscionability under the Uniform Commercial Code.

From this brief description, it is evident that the civil-law courts have applied code provisions similar to section 2-302 where the parties had no free choice or where the choice turned out to be a surprise to one of them. The criteria employed by the German and French courts are not unlike those present in our own cases circumventing the effect of harsh contracts or clauses. In light of these well-settled standards, a German court de-

95 See Prausnitz, op. cit. supra note 83, at 106-19; Dawson, Economic Duress and the Fair Exchange in French and German Law (pts. 1-2), 11 TuL. L. REv. 345, 12 Tul. L. REv. 42 (1937); Gutteridge, Abuse of Rights, 5 CAMB. L.J. 22, 40 (1933). See also PRAUSNITZ, op. cit. sipra note 83, at 90-105.

96 See note 87 supra.

97 For a development of the statutory terms, see Dawson, supra note 95, at 62-64. Dawson translates the terms as "necessity, inexperience or thoughtlessness."

08 Von Mehren, The Civil Law System 529 (1957).

09 See the opinions collected in Schlesinger, op. cit. supra note 90, at 355-65.

100 See Opinion of the German Reichsgericht in the Matter of Suedd. Transp. Vers. A.G., Plaintiff-Appellant, v. W., Defendant-Respondent, RGZ 106,386 (1st Civ. Div. 1923) (translated in Schlesinger, op. cit. sipra note 90, at 358).

101 Ibid.; Opinion of the German Reichsgericht in the Matter of G., DefendantAppellant v. St., Plaintiff-Respondent, RGZ 103,82 (1st Civ. Div. 1921) (translated in Schlesinger, op. cit. silpra note 90, at 355).

102 For an exception, see Henningsen v. Bloomfield Motors, Inc., 32 N.J. 358, 390-91, 161 A.2d 69, 87 (1960). 
claring a contract contrary to gute Sitten or a French court holding an agreement to be against bonnes moeurs or ordre public is invoking a rule of law quite distinct from what is conveniently termed public policy by our own courts. ${ }^{103}$ The operation of these civil-law principles is similar to that anticipated for the unconscionability provision of the Uniform Commercial Code: they have a distinct and defined area of application and are not merely decision-disguising catchalls which courts may invoke when a contract is too harsh to enforce and the law leaves no other loophole. This solution to the unconscionable contract has given the civil-law courts desirable flexibility, while at the same time encouraging them to meet the issue squarely. ${ }^{104}$ The civilian judge's handling of harsh contracts in terms of general principles may strain the traditional compartmentalized approach often associated with his common-law counterpart. But perhaps such a strain is in order in this corner of our contract law. ${ }^{105}$

\section{The Application of Section 2-302}

The disadvantages of the techniques presently relied upon by our courts to negative oppressive contracts stand out in bold relief against the civil-law experience. By distorting the construction of contract language, the courts have merely encouraged the draftsmen to become more skilled in phrasing a substitute. ${ }^{106}$ If one adaptation fails when subsequently tested by litigation, an infinite number of revisions still remain untried. That such a process breeds unnecessary litigation is obvious. Judicial use of these circuitous devices creates difficulty in yet another way: needless confusion in case-law development is engendered. Although a court might be hard pressed to distinguish one of its earlier unconscionability holdings expressed in terms of a particular contract doctrine, it is not likely to view it as controlling authority on the same contract issue where no defense of harshness is available. And the converse situation poses similar diffculties. In such potentially misleading circumstances, an attorney may fail to litigate a valid

103 See Prausnitz, op. cit. supra note 83, at 96.

104 There is one significant exception to the direct approach: the German and French tribunals construe standardized contractual terms strictly, in a fashion comparable to the construction of statutes. See PraUSNITz, op. cit. supra note 83, at 120-35.

105 "The experience of continental countries . . . suggests one conclusion that is of paramount importance for Anglo-American law-that is, the impulse for growth in case law which comes from imaginative generalization." Dawson, supra note 95, at 72 .

106 Compare Bekkevold v. Potts, 173 Minn. 87, 88, 216 N.W. 790 (1927), where the disclaimer read: "No warranties have been made in reference to said motor vehicle by the seller to the buyer unless expressly written hereon . . ." with Henningsen v. Bloomfield Motors, Inc., 32 N.J. 358, 367, 161 A.2d 69, 74 (1960). The disclaimer used in Henningsen is the one currently used by the trade. It should be noted that this revised version did not deter the Henningsen court from invalidating it. For an example of the advantages of the more direct approach, see Campbell Soup Co. v. Diehm, 111 F. Supp. 211 (E.D. Pa. 1952), where the court had no trouble upholding a grower-canner contract which was a completely revised, more equitable version of the agreement found unconscionable in Campbell Soup Co. v. Wentz, 172 F.2d 80 (3d Cir. 1948). See notes 73-82 supra and accompanying text. 
claim or defense, or he may press an argument when it has little chance of success.

Illustrations of two typical sales transactions may serve to highlight the contrast between the disadvantages inherent in the present treatment of harsh agreements and the improvements which section 2-302 would introduce into the law. Suppose Customer decides to purchase a substantial amount of lumber from Company for the purpose of repairing the roof on his house. After looking over several grains of wood and haggling over the price and the terms of payment, Customer agrees to take a specific type of lumber at the bargained price. On one of its printed agreement of sale forms, Company then fills in the price and the description blanks as agreed upon. Customer checks the price figures and signs the form without noticing the printed list of conditions on the reverse side, one of which stipulates that "all claims for defects in merchandise must be made within ten working days after the receipt of the goods." Four weeks after Customer installs the lumber, it proves defective and causes the roof to buckle.

In a state which has not adopted the Uniform Commercial Code, the issue would probably be framed as whether the defect was "latent" or "patent." 107 In such a case, a court which is reluctant to enforce the time limitation could easily label the defect "latent," provided the fault in the wood was not obvious to the naked eye. In this way, the ten-day limitation would be transformed into a rule of reasonableness and the four-week delay would probably not bar Customer's cause of action. ${ }^{108}$ [Such a decision might induce the Company to change its form contract and substitute a disclaimer of all express and implied warranties. But even this device holds little security for the Company: in future litigation, a court deeming the disclaimer unfair could ignore it by finding that the buyer was probably unaware of its existence at the time he contracted and thus that its inclusion in the agreement lacked mutual assent. ${ }^{109}$ In the course of this judicial juggling, "all claims for defects" is construed to mean "some," and a disclaimer of all warranties is sidetracked entirely. Or instead of changing its printed contract, Company might choose to retain the time limit provision and litigate any close case in the hope that another court might find another defect "patent." This is a high price to pay to enable a court to protect a party from a bargain he never made.

Section 2-302 is designed to do away with this indirect method of decision. The court is directed to look to the scope of the actual agreement entered into by the parties at the time of the sale. The presence of the form contract and the relative experience of the parties are considered in ascertaining the terms within the scope of the bargain. In order to measure the buyer's freedom of choice, the court might also inquire as to the extent to which such standard forms are uniformly used by all lumber

107 See note 59 supra and accompanying text.

108 See note 60 supra and accompanying text.

109 See the invitation for the courts to find "lack of mutual assent" in note 44 supra and accompanying text. 
dealers. The issue is what meaning was attached by the parties to the time limit condition. Did Customer read it as excluding after ten days all claims for defects regardless of their nature? Or did he believe it applicable to readily discoverable flaws only? Or did he ignore the fine print completely and merely make certain that the price per square foot was as agreed? If the court finds the understanding to be that the clause covered something less than all defects, it could apply section 2-302 and "limit" the time clause so as to allow Customer a reasonable notification period. A harsh provision-harsh because not bargained for-is thus deleted from the contract. Company now knows the real rationale of the court's decision and is not misled by a play on the contractual words; rather than attempt new schemes or continue to litigate old questions, Company will be alert to the necessity of bringing all enforceable terms to the buyer's attention in clear and unmistakable language before expecting a court to recognize and enforce such a provision under the Uniform Commercial Code.

In addition to being applicable to situations which involve "unfair surprise," section 2-302 is equally available to cope with the one-sided and oppressive contract.110 Suppose Automobile Buyer agrees to purchase a new sedan from Dealer. The agreement of sale contains the standard warranty suggested by the manufacturer which limits Dealer's liability solely to the replacement of parts which prove defective within ninety days or 4,000 miles. ${ }^{111}$ This "warranty" is called to Buyer's attention at the time of the sale. But since more than eighty per cent of all car manufacturers use the identical provision, Buyer has no choice but to take the car with the limiting warranty. Four months after the sale the motor begins to knock and has to be overhauled at substantial expense to Buyer.

In an action for breach of warranty in a state without the Code, a court would probably have no recourse ${ }^{112}$ except to recognize Dealer's defense based on the disclaimer, for the contract's language leaves little room for interpretation. ${ }^{113}$ Nor would an argument based on lack of mutual assent be available. But under section 2-302 relief from this oppressive contract is more easily obtained. Even assuming that the disclaiming warranty meets the standards imposed by section 2-316,114 Buyer would still have an argument based on unconscionability. If he can prove that free choice was precluded because of uniformity among leading car manufacturers in the

110 See note 12 supra and accompanying text.

111 For the actual language of the disclaimer, see note 41 supra. Recently, the auto manufacturers have extended the warranty to twelve months or 12,000 miles. Bus. Week, Nov. 26, 1960, pp. 55-56. But this warranty still limits buyer's remedy solely to replacement of defective parts.

112 But see Henningsen v. Bloomfield Motors, Inc., 32 N.J. 358, 161 A.2d 69 (1960), where the court voided the disclaimer on public policy grounds. See note 115 infra.

113 The use in the current warranty of the "all express or implied warranties" language has made the courts' role more difficult. See Hall v. Everett Motors, Inc., 165 N.E.2d 107 (Mass. 1960); cf. Wilson v. Eargle, 98 Ga. App. 241, 105 S.E.2d 474 (1958).

114 See note 66 supra and accompanying text. 
type of warranty offered, the otherwise valid disclaimer should be stricken under section 2-302.115

\section{Conclusion}

Although the legal profession is not unaware of the difficulties in the methods currently used by the courts in disposing of harsh contracts and clauses, concern over any restriction of "freedom of contract" often checks any concerted effort to empower the courts to "police explicitly" contracts of this type. Such alarm is unfounded. Section 2-302 evidences a realization that a contract is not a signature affixed to a long printed form but rather a mutual understanding reached through a process of bargaining. The provision merely gives the courts authority to strike or modify a contract where free choice is absent, or where a term of a contract to which the parties never agreed is invoked, or where a literal reading would extend the contract beyond all intention of the parties. Such action does not violate a realistic interpretation of "freedom of contract." The decisions emphasizing the presence of a form contract with fine print clauses, the relative experience of the parties, and in some cases the industry-wide uniformity of terms establish the criteria for refusing to enforce the contract that never was. Utilizing these guides, the courts will be able to enforce head-to-head contracts and void unconscionable agreements without constantly being thwarted by inflexible rules and inconsistent holdings. Far from limiting contractual liberty or disrupting commercial affairs, section 2-302 will contribute to the stability and freedom of contract. ${ }^{116}$

\section{J.H.A.}

115 For a recent case which emphasized this uniformity among automobile manufacturers in support of its refusal on grounds of public policy to give effect to the standard warranty, see Henningsen v. Bloomfield Motors, Inc., 32 N.J. 358, 161 A.2d 69 (1960). The facts of the Henningsen case suggest another possible interplay involving several sections of the Code. Automobile buyer's wife sued the manufacturer and his dealer for damages for personal injuries sustained when the car crashed into a wall because of a mechanical failure in the steering gear. There was insufficient evidence to make out a prima facie case of negligence and the case was given to the jury on a breach of warranty theory. The defense was based on the standard manufacturers' warranty. Assuming that the disclaimer could pass the test of UNIFORM COMMERCIAL CODE \$2-316, \$2-719(3) would seem to indicate that that part of the clause limiting "consequential damages for injury to the person" could still be found unconscionable under $\$ 2-302$.

116 This idea was eloquently expressed by Professor Kessler in Contracts of Adhesion-Some Thoughts About Freedom of Contract, 43 CouUM. L. REv. 629, 640 (1943): "The prestabilized harmony' of a social system based on freedom of enterprise and perfect competition sees to it that the 'private autonomy' of contracting parties will be kept within bounds and will work out to the benefit of the whole." 